\title{
Carl-Mario Sultana
}

ORCID: http://orcid.org/0000-0002-4610-8135

University of Malta

\section{COVID-19.}

\section{A Catechetical-Experiential Reading}

\begin{abstract}
This article seeks to give a Christian understanding to the reality of COVID-19 which the world has gone through in the past months. This is done in a catechetical way by elaborating upon what truly transforms a lived event into an experience and into a Christian religious experience through a catechetical process. This implies seeking to understand any lived event by reflecting upon it and then applying the results of one's reflection to one's life. This theoretical framework is then applied to the reality of COVID-19 with the aim of rendering the lived event of the pandemic into a Christian religious experience which leaves a positive effect on the lives of believers through a catechetical process of understanding it in the light of the Word of God, and then applying the outcomes to one's life afterwards.
\end{abstract}

\section{Keywords}

Christian religious experience, COVID-19, catechesis, human events.

COVID-19 has struck the world unawares in a silent yet at times deadly way. Although microscopic in size it has been able to stall and to halt the most conspicuous activities of the human being, or at best to reduce human activity to a dead slow pace. We can very reliably say that everybody was struck in some way or another by this pandemic which has spread to nearly all the countries 
in the world in a matter of weeks. ${ }^{1}$ Moreover, we can say that for our contemporary generations this is the first pandemic of its type. COVID-19 has been characterised by its non-discriminatory striking mode: it hits at anybody in a non-preferable way, from the youngest to the oldest. COVID-19 has demonstrated that it does not have any frontiers; it is not racist; it does not prefer somebody to somebody else; it strikes unsystematically and randomly. ${ }^{2}$ This state of affairs has left an impact on many human beings who have either totally halted or reduced their daily activities or have been forced to do so by decisions which have been made by the leaders of their countries in order to counteract the spread of COVID-19.

COVID-19 has also left many people locked up in their homes. This has given to many the opportunity to discover that things in life can be run in a different way. Moreover, spending a lot of time at home and refraining from going out has made many people undergo a form of extended retreat from daily activities. This has on its part made individuals re-think their priorities, and at times even to acknowledge that their priorities were not always correct. Amongst other things, one sees that $\mathrm{s} / \mathrm{he}$ can do without most of the things which we consider as daily necessities. Our daily necessities have also been reduced to what is truly necessary. The importance of family support and of supporting the most vulnerable have been somewhat rediscovered. Above all, we have rediscovered the importance of social responsibility, not only in giving a helping hand to the needy, but also in being responsible by refraining from going out if this is not absolutely necessary.

All this move in another direction can be totally annihilated if once we return to normal life, weshed all these positive values which we have been living in the past weeks and months. However, a truly catechetical and experiential re-reading of our living of the COVID-19 pandemic can help us to preserve these values and to have better priorities in life which are not only evident in the way we live, but which are also consonant with the faith which we profess.

1 Cf. Countries where COVID-19 has Spread: https://www.worldometers.info/coronavirus/ countries-where-coronavirus-has-spread/ (21.05.2020).

Cf. Why COVID-19 Kills some People and Spares Others. Here's What Scientists are Finding: https://www.livescience.com/why-covid-19-coronavirus-deadly-for-some-people. html (21.05.2020). 


\section{Catechesis throughout the Ages}

Throughout the ages, catechesis has been defined in several ways. The way in which catechesis was defined was usually influenced by the method or pedagogy which was prevalently used for catechesis itself. ${ }^{3}$ When catechesis was mostly performed by seeking to teach in question and answer by heart, catechesis consisted in teaching the Catechism. As a result, its definition was limited to this process in which children, young people and adults were taught the contents of the faith by heart through the Traditional Method. ${ }^{4}$ The dissatisfaction which the Traditional Method brought led to the developing of catechetical methods which were consonant with the developments in the area of psychology and of human communication. It was at this time that the Munich Method, which introduced formal steps in teaching, was introduced and adopted as the method which was to be used for catechesis. This transition started as far back as 1887 but the Munich Method was adopted as the method for catechesis at the Congress of Vienna in 1912. ${ }^{5}$ Within the context of the Munich Method, catechesis came to mean a pedagogical process by which children were introduced to the knowledge of the faith in a systematic way, from the known to the unknown and from the concrete to the abstract.

The Munich Method gave a lot of importance to the didactic and pedagogical procedure with which catechesis was conducted. At times, this was interpreted as being done at the expense of the contents of catechesis. This brought about another shift in catechetical method as from the 1930's where a more kerygmatic approach to catechesis was proposed. The Kerygmatic Method, as it became later known, was an attempt at putting the contents of the message at the centre of catechesis. However, this was not done in the way in which the Traditional Method used to, in a scholastic and rigid way. The Kerygmatic Method emphasised the

${ }^{3}$ Cf. E. Alberich, Catechesi, in: J. Gevaert (ed.), Dizionario di catechetica, Leumann (To) 1987, Editrice Elle Di Ci, p. 107.

4 Cf. G. Biancardi, U. Gianetto, Storia della catechesi. 4. Il movimento catechistico, Roma 2016, LAS, pp. 29-96; C.M. Sultana, Catechesis in Europe during the 20th Century, in: G. Bonney R. Vicent (eds.), Sophia - Paideia. Sapienza e educazione (Sir 1, 27). Miscellanea di studi offerti in onore del prof. Don Mario Cimosa, Roma 2012, LAS, pp. 423-424; A. Läpple, Breve storia della catechesi, Brescia 1985, Queriniana, pp. 181-188.

Cf. G. Biancardi, U. Gianetto, Storia della catechesi, pp. 165-186; C.M. Sultana, Catechesis in Europe during the 20th Century, pp. 424-425; A. Läpple, Breve storia della catechesi, pp. 196-201. 
message of the Gospels, citing Peter's speech at Pentecost as a paradigm for all catechesis. During this speech, Peter did not give formulas or creeds but he spoke of the experience of the apostles with Christ before and after his passion, death and resurrection. The Kerygmatic Method considered catechesis as the proclamation of the Good News of the Gospel. This method was accepted as the method for catechesis in $1960 .{ }^{6}$

Vatican Council II revolutionised the entire outlook of the Church: from a Church which was looking towards the inside in order to preserve the status quo, to a Church which was outward looking; a Church which was seeking to enter into dialogue with the human being. ${ }^{7}$ This brought about an anthropological shift in catechesis. Catechesis no longer considered the transmission of the knowledge of the faith as the one and only important thing in catechesis. Human beings now took the centre stage and were considered as a very important aspect of catechesis due to the fact that catechesis does not take place in a vacuum but it is directly linked to the human being and to the experiences which s/he are undergoing.

The new catechetical outlook adopted as a result of paradigm shift which was brought about by Vatican Council II also placed the Word of God in Sacred Scripture at the centre of all catechetical activity. This called for a new definition of what catechesis is and how catechesis has a direct impact on the human being through the Word of God. ${ }^{8}$

The history of salvation clearly demonstrates that God adapted a particular pedagogy to save the human being. It was only "when the fulness of time had come, [that] God sent forth his Son, born of woman, born under the law,

${ }^{6}$ Cf. G. Biancardi, U. Gianetto, Storia della catechesi, pp. 201-215; C.M. Sultana, Catechesis in Europe during the 20th Century, pp. 426-430; A. Läpple, Breve storia della catechesi, pp. 201-204.

Cf. E. Alberich, J. Vallabaraj, Communicating a Faith that Transforms. A Handbook of Fundamental Catechetics, Bangalore 2004, Kristu Jyoti Publications, pp. 164-168; E. Alberich, La catechesioggi. Manuale di catechetica fondamentale, Leumann (To) 2001, Editrice Elledici, pp. 170-175.

Cf. Vatican Council II, Dogmatic Constitution on Divine Revelation Dei Verbum (18 November 1965), https://www.vatican.va/archive/hist_councils/ii_vatican_council/ documents/vat-ii_const_19651118_dei-verbum_en.html (23.05.2020), 21; Congregation for the Clergy, General Directory for Catechesis (11 August 1997), https://www.vatican.va/ roman_curia/congregations/cclergy/documents/rc_con_ccatheduc_doc_17041998_directoryfor-catechesis_en.html (23.05.2020), 96, 127; C. Bissoli, "Và e annuncia" (Mc 5, 19). Manuale di catechesi biblica, Leumann (To) 2006, Editrice Elledici, pp. 179-229. 
to redeem those who were under the law, so that we might receive adoption as sons" (Gal 4, 4-5). God waited for the kairos to send his Son who was to show us that God was with us. This is a clear sign of God's pedagogy who did not want to save the human being outside history but in time and space. This brings us to the conclusion that the locus where the Word of God encounters the human being is through daily events which are rendered religious experiences through a process of interpretation and of personalisation. ${ }^{9}$

Moreover, the etymology of the term 'catechesis' shows that it a derivative of the Greek term katechein. The original meaning of the term in Greek is to echo, to resound, and to resonate. This means that catechesis is the bouncingoff of daily human events with the Word of God in order to give them a higher significance by considering them in the light of Sacred Scripture. In this respect, catechesis is an echoing of daily life experiences in the light of the Word of God. It consists of identifying and understanding one's daily experiences in the light of the faith. ${ }^{10}$

\section{Departing from Human Experience}

If catechesis as the echoing and interpreting of human experiences in the light of the Word of God is to be a significant and effective process which really touches the deepest aspect of the human being, we need to depart from human experiences, because this is where God still seeks to encounter the human being today. A human experience can be described as a three-fold movement. It starts from a lived reality which is undergone in an intense way, and not in a superficial way. Once this happens, the person living that reality may seek to give it a deeper meaning by trying to understand not only its dynamics, but also how it fits within all that s/he has already undergone and all that s/he affirms as important in life. It is at this point that the event or lived reality is given a deeper meaning, and not just living it in a superficial way. Finally, once a new significance is given to the event, one may draw the new meaning which this

Cf. E. Alberich, Identità e dimensioni fondamentali della catechesi, in: E. Alberich U. Gianetto, Andate e insegnate. Manuale di catechetica, Leumann (To) 2002, Editrice Elledici, pp. 89-90; E. Alberich, J. Vallabaraj, Communicating a Faith that Transforms, p. 103; E. Alberich, La catechesi oggi, pp. 107-108.

${ }^{10}$ Cf. Catechesi: in: Dizionario, p. 107; E. Alberich, J. Vallabaraj, Communicating a Faith that Transforms, pp. 112-114; E. Alberich, La catechesi oggi, pp. 116-118. 
has been given and apply it to one's life. It is only at this moment, that is, when the lived and interpreted reality brings about a positive change in the life of the individual that we can speak of a complete cycle starting from an event in one's life and working through it to become an experience which influences the entire life of the individual. ${ }^{11}$

A human occurrence can achieve a religious significance and become a religious experience if it is interpreted using some form of religious criteria. This usually happens when the human being undergoing the event cannot find a plausible and adequate interpretation on a human level, and so seeks to understand the mystery which is shadowing and underlying the lived reality. When this is sought, the human being undergoing the event seeks to go deeper down into the meaning of the event. This is done in such a way that the acceptance of human finiteness in giving the event a plausible interpretation opens the individual to the Transcendent. At this stage we can say that the individual has crossed the threshold of mystery and enters into the realm of the Transcendent. It is only when one has crossed this line that the human experience becomes a religious experience which therefore gives a deeper meaning to the human event, rendering it a religious experience. Being an experience of a religious nature, the application of the interpretation to daily life is usually visible through rites, customs and rituals which are pertinent to the tradition within which one is manoeuvring. ${ }^{12}$

A Christian religious experience is arrived at from a religious experience simply by applying Christian criteria in the interpretation of the event or daily life experience. What is specific to the Christian faith is that it is built on three parallel tracks. Each one of these tracks in its own right helps the individual to give an adequate interpretation to daily life events, by shedding light on them and by making them echo and resonate in the light of the Word of God. ${ }^{13}$ The three parallel tracks against which human events are echoed are: the experience of the People of God in the Old Testament, the experience of Christ and of the first Christian communities in the New Testament, and the experience of the entire Church through it entire 2000 year life, history, teachings and presence.

${ }^{11}$ Cf. E. Alberich, J. Vallabaraj, Communicating a Faith that Transforms, pp. 103-105; E. Alberich, La catechesi oggi, pp. 108-110.

${ }^{12}$ Cf. E. Alberich, J. Vallabaraj, Communicating a Faith that Transforms, pp. 105-107; E. Alberich, La catechesi oggi, pp. 110-111.

13 In this instance the term Word of God refers to both Sacred Scriptures and to the Tradition of the Church. 
All this will form the backdrop against which the daily life events of the believer can be bounced in order to give them a more significant and deep meaning. ${ }^{14}$ This is done with the aim of drawing aspects from them which can be lived in a practical way from then onwards.

In the light of what a Christian religious experience is, we can therefore define catechesis as the process of interpreting and communicating meaningful life experiences in the light of the faith of the People of Israel as this is found in the Old Testament, of the teachings of Christ and of the life of the early Christian community as this is found in the New Testament and of the entire life, history, teachings and Tradition of the Church, with the aim of bringing about a positive change in life by applying it to one's life. ${ }^{15}$ Therefore catechesis is ultimately the re-reading, the understanding, the interpreting, and the application of the light which the Word of God sheds on human activities and human endeavours.

\section{A Catechetical and Experiential Interpretation of COVID-19}

COVID-19 has proved to be a human event which has dealt a terrible blow on the activities of human beings. Indeed, some have lived it as a tragedy, since it has hit hard on them, even to the point of taking some loved one away through death. Since COVID-19 is a human event, it can also be the subject of study in order to be able to understand it as a phenomenon, and to interpret it with the ultimate aim of making out of it a truly human and Christian experience which really impacts the human being in a positive way. A catechetical interpretation of the COVID-19 phenomenon in the world helps us not only to come to terms with our true human condition, but it will also help us to draw some positive aspects which we can live in a practical way in our lives as believers as from now on.

As for all other human experiences which are rendered into religious and Christian religious experiences which seek to have an impact on the life of the individual, the three-step process of what makes an experience truly so, needs to be undertaken. In this particular case, the event is the phenomenon of the pandemic itself. This reality which we are undergoing needs to be read,

${ }^{14}$ Cf. E. Alberich, J. Vallabaraj, Communicating a Faith that Transforms, pp. 107-108; E. Alberich, La catechesi oggi, pp. 112-113.

${ }^{15}$ Cf. E. Alberich, J. Vallabaraj, Communicating a Faith that Transforms, p. 113; E. Alberich, La catechesi oggi, pp. 117. 
interpreted and understood in the light of Word of God. We will them be in a better position to apply our interpretation and the conclusions reached to our lives as from now on, in the hope of bringing about a positive change in our lives.

\subsection{The Reality of COVID-19 in the World}

The first instances of COVID-19 to date were discovered and reported in Wuhan, China on $31^{\text {st }}$ December 2019. ${ }^{16}$ It was described by the World Health Organisation as "a pneumonia of unknown cause." ${ }^{\text {"17 }}$ The World Health Organisation worked tirelessly to seek to clinically define this new virus and to understand it in order to be able to control it as much as possible. Notwithstanding this, and due to the rapid spreading of the virus, it was declared a Public Health Emergency of International concern on $30^{\text {th }}$ January 2020 . On $11^{\text {th }}$ February 2020, the World Health Organisation gave the official name of COVID-19 to the virus. Since the outbreak and the spread of the virus was proving to be uncontrolled by seasonal and by temperature changes in different parts of the world, and since it had travelled around the globe in a swift manner regardless of the seasonal changes as the normal influenza virus does, the outbreak and spread of the disease were classified as a pandemic on the $11^{\text {th }}$ March 2020. ${ }^{18}$

The rapid spread of COVID-19 has been largely aided by our modern lifestyle as human beings, especially travelling, and our endeavours as businessminded human beings. As human beings in a society which is constantly out and about, not only in our native countries but also in foreign countries, COVID-19 has found the best way to spread to all countries in a very short span of time by being carried around and transmitted by the human species. It seems that there are no countries which have not been hit, hard or otherwise, by COVID-19. Therefore, the reality of having to live and cope with an invisible enemy has touched all human beings in whatever country they happen to be residing.

16 This has lately been contested by a report which states that in France there was a case which was diagnosed on 27th December 2019. One may cf. Coronavirus was Circulating in France in December, Case Report Suggests, https://www.livescience.com/coronavirus-francepatient-zero-december.html (21.05.2020).

${ }^{17}$ Cf. World Health Organisation, Rolling updates on Coronavirus Disease (COVID-19), https://www.who.int/emergencies/diseases/novel-coronavirus-2019/events-as-they-happen (23.04.2020).

${ }^{18}$ Cf. World Health Organisation, Rolling updates on Coronavirus Disease. 
But how are we as human beings living the reality of COVID-19? The virus has shown itself as being an intrusive virus which lies hidden like a venomous snake which is ready to attack its prey unawares. Although the human being is constantly seeking to dominate the earth and all living creatures, COVID-19 has used its microscopic existence to cut the human being down to size. One of the characteristics of COVID-19 is its indiscriminate way of attacking the human being. This brings to mind the episode in Num 21,1-9 when during the passage of God's chosen people to the Promised Land after their Exodus from Egypt, they encountered poisonous snakes in the desert which started biting the people indiscriminately and killing some of them.

As a virus, it is unintelligent, but it is always ready to enter into and to reside in whoever it encounters, and wherever a door may be open. In our eyes, this makes it very dangerous, because we can never be sure that we will not be struck by it. If we had to look at the demographics of where COVID-19 hit, we can see that it shows no preferences. It hits wherever this may be. It is transmitted in the quietest way possible and it strikes indiscriminately without taking any notice of race, colour or social position. All human beings can be struck by COVID-19 in an equal way. ${ }^{19}$ For us human beings, who are constantly seeking to preserve and lengthen our life, this issue is of very grave concern. The greatest concern of human beings is the fear of the unknown; the fear of tomorrow and what it will bring about.

COVID-19 though invisible has not only entered secretly into the lives of the human beings which it struck, but it has also created havoc to one of the things which human beings hold at heart: health. This is because when the health of the human being is struck, it is the same life of the human being which is at stake. COVID-19 has proved to sting the human being where it is actually very painful, not only physically but also emotionally. It has threatened the human being with his/her very existence here on earth. But the effects of COVID-19 do not stop here.

The danger to the health of individuals which COVID-19 brought about has led the leaders of most countries to impose a state of social distancing on their citizens. At times, people were being hit so hard by contamination with the virus that some nations have also imposed a state of either total lockdown

19 Cf. John Hopkins University of Medicine, Coronavirus Resource Centre, https:// coronavirus.jhu.edu/map.html (24.04.2020). 
or a lockdown for categories of vulnerable people. ${ }^{20}$ This took place besides the normal obligatory quarantine rules and isolation for people who had been infected or had come in touch with somebody who was infected. The social distancing which was called for in many countries has also had devastating effects on individuals, especially those who are more vulnerable due to a very mature age and to those who have particular health conditions which require constant monitoring and therapy. Social distancing rules have brought about anxiety in many individuals who fear being contaminated by the virus. ${ }^{21}$ Many have justifiably uttered: 'Now we really know what we are missing out in life!'

Social distancing has left a deep scar on the elderly, especially grandparents who were asked to refrain from personally meeting their grandchildren with the resulting heightened emotional instability which this brought about. This has been partially remedied for through using electronic means to see and to communicate with each other. However, there are also cases when the elderly are not well equipped or trained to use such electronic means and so they easily become socially isolated. This can be the case where we have an aged person who lives by him/herself with no other relatives who can take care of them. Such individuals have become stuck at home all by themselves. But not all is negative. Such instances have also at times triggered the solidarity of the neighbours who have come to the aid of such vulnerable individuals and who are now being cared for by their neighbours in terms of errands for food and medicine supplies.

COVID-19 has had a devastating impact on businesses which are considered as non-essential and which have had to close their doors in the wake of the pandemic. ${ }^{22}$ COVID-19 has been able to bring the economy of many countries to a standstill. Many businesses have been halted or drastically reduced. Some have even sent their employees on either a three/four-day week or simply put

${ }^{20}$ Coronavirus: 'London-only lockdown' was considered by government, in: $B B C$, https://www. bbc.com/news/uk-england-london-52325933 (24.04.2020); Trentagiorni di lockdown in Italia raccontati in diecigrafici, in: Il sole 24 ore, https://www.infodata.ilsole24ore.com/2020/04/09/ trenta-giorni-di-covid-19-raccontati-in-dieci-grafici/?refresh_ce=1 (24.04.2020); B. Borg, As it Happened: Lockdown Confusion as Malta reaches 139 Coronavirus Cases, in: Times of Malta, https://timesofmalta.com/articles/view/live-blog-coronavirus-updates.781202 (25.04.2020).

21 A. Mohdin, Rise in Depression and Anxiety Day after UK Lockdown Announced - Study, in: The Guardian, https://www.theguardian.com/world/2020/mar/31/rise-in-depression-andanxiety-day-after-uk-lockdown-announced-study-coronavirus (24.04.2020).

${ }^{22}$ COVID-19: The EU Plan for the Economic Recovery, in: News European Parliament, https://www.europarl.europa.eu/news/en/headlines/economy/20200513STO79012/covid-19the-eu-plan-for-the-economic-recovery (21.05.2020). 
on unpaid leave. Some workers have also been laid off as redundant personnel. This has impacted the income of many families, not only of the stake holders in business, but also in a special way those unskilled workers who have a basic pay which has been reduced due to less hours of work, or totally stopped due to unpaid leave or by termination of employment. This dire state of the economy and of the availability of work has brought about the rise of the contemporary poor people in our society, that is, those who lack the essentials for everyday life. ${ }^{23}$

One of the collateral effects of COVID-19 seems to be the fear of other persons. Whilst before the spread of the pandemic we were all out and about socialising, today we are fearing and shunning other human beings. People seem to be afraid of each other because they do not know if the interlocutor is a carrier of COVID-19. This is leaving a very strong impact on our lives as social human beings. We were made to be with each there and not to avoid each other. This reality is even more felt by those who have contracted the virus even after they have overcome COVID-19. Such individuals are being stigmatised and put aside as if they have lost their dignity as human beings. ${ }^{24}$

COVID-19 as an event has been traumatic for the human being. It has drastically severed the social and relational ties between groups of individuals who have kinship ties. The pandemic has dealt a very strong blow to our social and financial welfare. This is the picture, which is mostly negative, as we see it as human beings. In order to make sense of all this, we need to read it in the light of the Word of God. Only the Word of God can shed an adequate light on this contemporary human situation and render it a formative event which can shed light on how we can live our life as from now on.

${ }^{23}$ Coldiretti, con lockdown un millione di nuovi poveri, in: Qui Finanza, https://quifinanza. it/finanza/coldiretti-con-lockdown-un-milione-di-nuovi-poveri/374952/ (27.04.2020); B. Fox, Half a Billion People Face Poverty after COVID-19, in: Euractiv, https://www.euractiv.com/ section/coronavirus/news/half-a-billion-people-face-poverty-after-covid-19/ (27.04.2020).

24 P. Corrigan, On the Stigma of COVID-19, in: Psychology Today, https://www. psychologytoday.com/us/blog/the-stigma-effect/202004/the-stigma-covid-19 (27.04.2020); COVID-19 (Coronavirus) Stigma: What it is and How to Reduce it, in: Mayo Clinic, https://www. mayoclinic.org/diseases-conditions/coronavirus/in-depth/coronavirus-stigma/art-20484278 (27.04.2020). 


\subsection{Light from the Word of God}

The way COVID-19 has struck the human being in all the different spheres and strata of life brings the theological dilemma of theodicy to the forefront. Many believers have spontaneously uttered the opening verses of Ps 22, 1-2: "My God, my God, why have you forsaken me? Why are you so far from helping me, from the words of my groaning? O my God, I cry by day, but you do not answer; and by night, but find no rest." This reaching out for God in times of distress shows the faith of the believer, who at the same time cannot understand the devastation which such human tragedies bring about. However, it is only the Word of God which can shed a truly illuminating ray of light on such complex human situations.

In our interpreting the event of COVID-19, we need to be very clear as from the very beginning about the way in which this situation needs to be interpreted. There have been many people who have seen this event as a form of punishment for the lax way in which contemporary human beings are conducting their endeavours. This interpretation is not correct. God has neither created this contagion to punish the human being, nor has he taken the side of the virus against human beings. COVID-19 is not a punishment from God because we can all be struck rich and poor alike in an equal way. Poor people, who are closer to God and cling to him more, because they have no other mundane things to which to hold fast to, seem to be more prone to contract COVID-19 due to poor living conditions and a fragile health. This brings to mind the episode from the Gospel of Luke $(13,1-5)$ which narrates the story of when Pontius Pilate mixed the blood of some Jews with the blood of their sacrifices, and of the Tower of Siloam which fell indiscriminately on the people. Jesus clearly said that these victims were not worse than the others. This happened to them not because they were more sinful than the rest. The conclusion of this is that God is still our ally; he is not on the side of the virus. God is not judging us. Still, we need to judge ourselves in the light of this situation. ${ }^{25}$

Incidentally, COVID-19 struck the world with its fullest force during the lenten and Easter period. There is no better way to seek to understand and interpret this human event of COVID-19 than through the Paschal Mystery - the passion, death and resurrection of Christ. This is because COVID-19 is being

25 Pope Celebrates Passion of the Lord, as Papal Preacher Reflects on COVID-19 Pandemic, in: Vatican News, https://www.vaticannews.va/en/pope/news/2020-04/pope-francis-passionof-the-lord-cantalamessa-sermon-coronavirus.html (28.04.2020). 
considered by many as a cause of death not only through the physical end of human life for some who have contracted the virus, but because it has also brought about emotional deaths in many relationships and friendships which had to be severed through social distancing.

The uttering of a plea to God who seems to have abandoned his people however is not the last word in this human event. While COVID-19 can be seen by many as an injustice which was inflicted on the world by others, we are positively sure that it is not the greatest injustice every inflicted on a human being. We can rightly say that the greatest injustice inflicted on a human being was endured by Jesus Christ who although blameless, carried the burden of the sinfulness of all human beings. It is exactly this reality which helps us to give a valid interpretation to the human event of COVID-19. But the event of the death of Jesus was not the last episode. The mystery of Christ's death does not end on the cross or in the tomb, but in the empty tomb. The resurrection of Christ is the last word of God to all human failings and to human sinfulness. Our God is a God of life and not of death. He wants us to live and to live life to the full.

The narrative of the first appearance of the risen Christ according to the Gospel of John $(20,19-21)$ forms the best backdrop against which we can interpret both the event of COVID-19 and also the emotions generated by such a situation in which all human beings have found themselves. In this pericope, the disciples are locked inside due to fear of the Jews in the light of what had happened to Jesus on the days before. Suddenly, Jesus appears in their midst not only to comfort them but also to sustain them in their faith.

At this present moment in life, due to COVID-19, many have been induced into a form of prolonged retreat at home. At times, this has been forced on the human being and like the disciples, we are also emotionally distressed and alone with our fears and hopes which may at times be false hopes as well. Like the disciples gathered together, we also have ample time to ponder on our past and to see the frugality of our way of life in the past. Looking back at our lives in this prolonged retreat, we can find that at times even God did not feature as an important part of our life, and like the disciples we find ourselves living our lives without Christ, or with minimal reference to him. Moreover, in the peace and the quiet of the newly adopted lifestyle, we can get in touch with our real selves, and make space for a personal encounter with Jesus.

The first words of Jesus to his disciples were not a cold shower as one would expect as a result of their unbelief, and of having deserted him in such a critical moment. The words of Jesus were words of reconciliation, harmony and serenity: 
"Peace be with you" (Jn 20, 19b). As Jesus went to meet his disciples with peace, he still does so today: he comes to encounter us in our failings, in our finiteness, and in our limitations as human beings with peace - a peace which only he can give and which the world cannot give; a peace with which we can put our hearts at rest $(J n 14,27)$. This peace which the risen Christ bestowed on his disciples and which he is still actively seeking to give to us has to be seen also in the light of his promise that he will never leave us alone, and that he will be with us till the end of time, no matter what we go through (Mt 28, 20).

Being human beings, we are still afraid of many things and of many ideas which distress us. Amongst other things, during the period of COVID-19 many individuals had a fear of tomorrow, a fear of something which is unknown. Moreover, the period of social distancing which has been characteristic of the many ways which were used to combat COVID-19 has had a tremendous effect on many people. The period of time in which people were forced to stay indoors except for exceptional circumstances has made human beings aware of how precarious their life is. The prolonged times of silence, and at times of solitude has made people afraid to get in touch with their real selves through silence. What has silence exposed of our real selves? It has shown the human beingstheir past which was at times made of superficial beliefs or even periods of non-belief, and in the present circumstances of COVID-19, the human being's lack of trust in God. We can say that in such instances, silence speaks much louder than words, and can help the human being get in touch with his/her existential self in a much effective and efficient way.

In the risen Christ we are all called to overcome our fears and limitations. The marks of the violent death which he had endured days before and which he now showed to the disciples on this first visit after the resurrection (Jn 20, 20) are a sure sign that he had overcome the biggest of the enemies of the human being - death. Throughout the dark moments of our lives, we need to recall that Christ has had the ultimate word on death, which is our worst enemy. We need to recall that we can encounter and overcome any difficulty which we meet in our lives in the light of Christ's passion, death and resurrection which in reality has opened to us a new destination. This future destination is something which we have to work for in this life but which we will experience fully in the afterlife. Our life is not destined to end with the end of human life on earth, but we are called to prepare ourselves to enter fully into the Kingdom of God in the afterlife.

The meeting with the risen Christ which several of the disciples had, was a turning point in their life. This is evident in the meeting which the disciples 
who were on their way to Emmaus had with the risen Christ, and how the dialogue which ensued from this meeting led them to a change of mind and heart (Lk 24, 13-35). After meeting the risen Christ who kindled their heart with his words and then showed himself during the breaking of the bread, these disciples could not retain the position which they had taken: that of returning to their normal life after a disillusioning experience which they had in Jerusalem. Likewise, our encounter with the risen Christ through faith cannot slip away from within our grasp without bringing about a change in us. Meeting the risen Christ through faith, we are induced to change our life in a positive way, after a time of spiritual fasting and reflection.

In all this endeavour, faith is essential. The type of fight which we require is not that which rests within the limitations of human power or potentiality as human beings, but a solid faith in Jesus Christ who overcame death. It is faith in the power of the risen Christ which helps us embark on a new journey of hope; a journey which distances itself from the life which we lived in the past, to a new way of life which is characterised by faith in Christ and an appropriation of what we have learnt through our reflection on daily events interpreted in the light of the Word of God.

\subsection{An Application to Life Hereafter}

A third and final step in the itinerary of rendering any human event a Christian experience is the application of what has been learnt through living the event and through reflecting on it in the light of the Word of God. St Peter in his first letter vehemently asks believers in Christ to be ready to give a whole-hearted witness of their hope to all who in this world call this of them (1 Pt 3, 15b). This is the witness which we are called to give to the entire world as Christians as a result of having gone though this experience of COVID-19. This witness can take several different nuances and particular shades.

The first things which we as human beings and especially as believers are called to give witness to in the post-COVID-19 days are our priorities, especially those which are strictly related to the values which we seek to live in our daily life. COVID-19 has shown us that technology cannot save us; neither can any amount of money be useful in the particular conditions of a pandemic. These facts urge to seek to study and to understand where we have put our strongholds. If before the emergence of COVID-19, we have put our trust in money, or in technology, or in any other human power, now we know that these can be useful 
only to some extent, and that they are useless when our very life is threatened with extinction. Moreover, as Jesus taught us through the parable of the rich fool and the abundant harvest, such riches are futile when we are called to give to God an account of our deeds ( $\operatorname{Lk} 12,13-21)$. If COVID-19 is to leave a positive effect on us, we are called to review where we have put our trust, and to return to the real and true source of our hope which does not fail: "Heaven and earth will pass away, but my words will not pass away" (Mt 24, 35). Most of all, we need to re-think about our priorities in life, and to put the things which should be first in the first position, and then all the rest will fall in its proper place.

Authenticity is the mark of the believer in Christ. The words of St Peter to women in his first letter are applicable to all human beings equally, no matter their race or status. The words of St Peter: "Do not adorn yourselves outwardly by braiding your hair, and by wearing gold ornaments or fine clothing; rather, let your adornment be the inner self with the lasting beauty of a gentle and quiet spirit, which is very precious in God's sight" (1 $\mathrm{Pt} 3,3-4)$ can prove to be a project for the life of believers in the aftermath of COVID-19. Pope Francis has constantly insisted on Catholics to live a truly authentic life which is in line with what they profess in their faith. ${ }^{26}$ An application of what has been learned though the human event of COVID-19 to daily life should feature the searching for, and the living of authentic human and Christian values in daily life endeavours.

One of the authentic human and Christian values which all believers are called to live in the aftermath of COVID-19 is the value of solidarity and mutual help. We need to show solidarity and offer a helping hand to all, especially the poor and those who seem to have been abandoned by contemporary society since they cannot contribute anything for the financial and economic welfare of society. COVID-19 has already given us the opportunity to see and to experience the fact that no matter how much money or financial stability one has, we are ultimately all human; we are all vulnerable and therefore all are in the same situation as human beings, and we all need the help of others, while helping others ourselves. We are all interdependent. Pope Francis in his homily on Divine Mercy Sunday 2020 clearly defined the way forward for all believers: we cannot keep on avoiding the poor and those rejected by our society;

${ }^{26}$ Amongst the many references of Pope Francis to authenticity in daily life, we find: http:// w2.vatican.va/content/francesco/en/audiences/2018/documents/papa-francesco_20180822_ udienza-generale.html (05.05.2020). 
we cannot keep on choosing with whom to be and neglecting the others. ${ }^{27} \mathrm{In}$ terdependence and mutual solidarity and help, even if this cannot be returned, are to be the distinctive sign of believers in Christ.

The devastation and death which COVID-19 is leaving in some parts of the world can lead the human being to lose hope or to even enter into a state of despair. This is the reason why on many television stations and especially on the social media, a new phrase has been introduced which states that we will rise again after the challenge of COVID-19. ${ }^{28}$ Here, the reference is to the return to a normal life-style and to a social life after the disruption and the devastation caused by COVID-19. However, our vulnerability as human beings and as believers also helps us to understand that God is calling us to see and to understand that all will be restored in Christ. In this sense, our rising up again will not be like Lazarus' restoration to life by Jesus (Jn 11, 1-44). Lazarus was restored to life by Jesus for a temporary period, after which he had to die once again. In the light of our faith in Jesus Christ who overcame death by life, we are called to rise up as he did on the first day of the week: glorious, changed and restored to integrity, as we pray in the prayer after the seventh reading of the Easter Vigil: "may the whole world know and see that what was cast down is raised up, what had become old is made new, and all things are restored to integrity through Christ...”29 In the aftermath of COVID-19 we need to resume our activities as human being with a new outlook: while being in this world, and immersed in its activity, we still know that we are not of the world (Jn 15, 19 and Jn 17, 14-16), and that we are called to be with God in the afterlife. This is the renewed life which we are called to live in the aftermath of COVID-19.

27 Pope Francis, Holy Mass on the Liturgical Feast of Divine Mercy, in: http://w2.vatican. $\mathrm{va} /$ content/francesco/en/homilies/2020/documents/papa-francesco_20200419_omeliadivinamisericordia.html (05.050.2020).

${ }^{28}$ Good Infinite, COVID-19. We Will Rise Again, in: https://www.facebook.com/ 110341993909995/videos/2960725577349661/ (05.05.2020).

${ }^{29}$ Holy Saturday, in:https://onlineministries.creighton.edu/CollaborativeMinistry/Lent/ v-prayers.html\#II (05.05.2020). 


\section{Conclusion}

For anyone who wants to learn from COVID-19, we have a myriad of ways which we can apply to life. ${ }^{30}$ COVID-19 has radically changed our way of living and of being together. But is this temporary? If we truly lived this human event of COVID-19 as a Christian religious experience, we will surely note that this endeavour has brought about positive changes in our life. However, being human we also like to return to the roots and to the old ways which we considered as secure, even though reality has shown us otherwise. This is a very realistic temptation which can stall all our efforts to bring about change both in ourselves and in the world around us.

One of the outcomes from which we need to guard ourselves and of which we need to be constantly aware is that we are not return to the life-style and the way of life which we used to live before COVID-19. Had this to be so, then we can confidently say that the event of COVID-19 has not been a true experience which has changed us. If this were to be so, the human event of COVID-19 remains only a dark event marked in the history of humanity and not a truly Christian experience which has radically changed us in a positive way.

\section{Bibliography}

Alberich E., Vallabaraj J., Communicating a Faith that Transforms. A Handbook of Fundamental Catechetics, Bangalore 2004.

Alberich E., Catechesi, in: Dizionario di catechetica, (ed.) J. Gevaert, Leumann (To) 1987, pp. 104-108.

Alberich E., Identità e dimensioni fondamentali della catechesi, in: Andate e insegnate. Manuale di catechetica, (eds.) E. Alberich - U. Gianetto, Leumann (To) 2002, pp. 80-95.

Alberich E., La catechesi oggi. Manuale di catechetica fondamentale, Leumann (To) 2001. Biancardi G., Gianetto U., Storia della catechesi. 4. Il movimento catechistico, Roma 2016. Bissoli C., "Và e annuncia" (Mc 5, 19). Manuale di catechesi biblica, Leumann (To) 2006. Borg B., As it Happened: Lockdown Confusion as Malta reaches 139 Coronavirus Cases, in: Times of Malta, https://timesofmalta.com/articles/view/live-blog-coronavirusupdates.781202 (25.04.2020).

Cini F., Invitation of the Present Moment, in: Times of Malta, https://timesofmalta.com/ articles/view/invitation-of-the-present-moment.792587 (22.05.2020).

${ }^{30}$ F. Cini, Invitation of the Present Moment, in: Times of Malta, https://timesofmalta.com/ articles/view/invitation-of-the-present-moment.792587 (22.05.2020). 
Coldiretti, con lockdown un millione di nuovi poveri, in: QuiFinanza, https:/quifinanza. it/finanza/coldiretti-con-lockdown-un-milione-di-nuovi-poveri/374952/ (27.04.2020).

Congregation for the Clergy, General Directory for Catechesis (11 August 1997), https:// www.vatican.va/roman_curia/congregations/cclergy/documents/rc_con_ccatheduc_doc_17041998_directory-for-catechesis_en.html (23.05.2020).

Coronavirus was Circulating in France in December, Case Report Suggests, https://www. livescience.com/coronavirus-france-patient-zero-december.html (21.05.2020).

Coronavirus: 'London-only lockdown' was considered by government, in: BBC, https:// www.bbc.com/news/uk-england-london-52325933 (24.04.2020).

Corrigan P., On the Stigma of COVID-19, in: Psychology Today, https://www.psychologytoday.com/us/blog/the-stigma-effect/202004/the-stigma-covid-19 (27.04.2020).

Countries where COVID-19 has Spread: https://www.worldometers.info/coronavirus/ countries-where-coronavirus-has-spread/ (21.05.2020).

COVID-19 (Coronavirus) Stigma: What it is and How to Reduce it, in: Mayo Clinic, https:// www.mayoclinic.org/diseases-conditions/coronavirus/in-depth/coronavirus-stigma/ art-20484278 (27.04.2020).

COVID-19: The EU Plan for the Economic Recovery, in: News European Parliament, https://www.europarl.europa.eu/news/en/headlines/economy/20200513STO79012/ covid-19-the-eu-plan-for-the-economic-recovery (21.05.2020).

Fox B., Half a Billion People Face Poverty after COVID-19, in: Euractiv, https://www. euractiv.com/section/coronavirus/news/half-a-billion-people-face-poverty-aftercovid-19/ (27.04.2020).

Good Infinite, COVID-19. We Will Rise Again, in: https://www.facebook.com/110341993909995/ videos/2960725577349661/ (05.05.2020).

Holy Saturday, in: https://onlineministries.creighton.edu/CollaborativeMinistry/Lent/vprayers.html\#II (05.05.2020).

John Hopkins University of Medicine, Coronavirus Resource Centre, https://coronavirus. jhu.edu/map.html (24.04.2020).

Läpple A., Breve storia della catechesi, Brescia 1985.

Mohdin A., Rise in Depression and Anxiety Day after UKLockdown Announced - Study, in: The Guardian, https://www.theguardian.com/world/2020/mar/31/rise-in-depressionand-anxiety-day-after-uk-lockdown-announced-study-coronavirus (24.04.2020).

Pope Celebrates Passion of the Lord, as Papal Preacher Reflects on COVID-19 Pandemic, in: Vatican News, https://www.vaticannews.va/en/pope/news/2020-04/pope-francispassion-of-the-lord-cantalamessa-sermon-coronavirus.html (28.04.2020).

Pope Francis, Holy Mass on the Liturgical Feast of Divine Mercy, in: http://w2.vatican.va/ content/francesco/en/homilies/2020/documents/papa-francesco_20200419_omeliadivinamisericordia.html (05.050.2020).

Pope Francis, http://w2.vatican.va/content/francesco/en/audiences/2018/documents/ papa-francesco_20180822_udienza-generale.html (05.05.2020). 
Sultana C.M., Catechesis in Europe during the 20th Century, in: Sophia - Paideia. Sapienza e educazione (Sir 1, 27). Miscellanea di studi offerti in onore del prof. Don Mario Cimosa, (eds.) G. Bonney, R. Vicent, Roma 2012, pp. 423-450.

Trenta giorni di lockdown in Italia raccontati in dieci grafici, in: Il sole 24 ore, https:// www.infodata.ilsole24ore.com/2020/04/09/trenta-giorni-di-covid-19-raccontati-indieci-grafici/?refresh_ce=1 (24.04.2020).

Vatican Council II, Dogmatic Constitution on Divine Revelation Dei Verbum (18 November 1965), https://www.vatican.va/archive/hist_councils/ii_vatican_council/ documents/vat-ii_const_19651118_dei-verbum_en.html (23.05.2020).

Why COVID-19 Kills some People and Spares Others. Here's What Scientists are Finding: https://www.livescience.com/why-covid-19-coronavirus-deadly-for-some-people. html (21.05.2020).

World Health Organisation, Rolling updates on Coronavirus Disease (COVID-19), https:// www.who.int/emergencies/diseases/novel-coronavirus-2019/events-as-they-happen (23.04.2020). 